\title{
A HOUSE ON SALE FOR A HOMECOMING. THE UNHOMELY SEMANTICS OF POST-APARTHEID SOUTH AFRICA
}

Anderson Bastos Martins

Universidade Federal de São João del Rei

\begin{abstract}
This article is a biographical study of Nadine Gordimer through a dialogue staged between three of her characters-Helen Shaw, Rosa Burger and Vera Stark-and one of her essays. The object of the study is to retrace Nadine Gordimer's steps in her long journey that allowed her to assume and experience not only a nationality but also a sense of belonging to Africa as an African rather than a colonial.
\end{abstract}

Keywords: biographical criticism, nationality, belonging, exile, staying.

\section{Introduction}

Despite a somewhat hurried critical analysis, Nadine Gordimer's vast writing career has not gravitated solely around the all-imposing theme of racial relations in her home country. And among the various other topics treated by the author in her works, exile, and to a lesser

\begin{tabular}{|l|l|l|l|l|}
\hline Ilha do Desterro & Florianópolis & $n^{\circ} 61$ & p. 199-223 & jul/dez 2011 \\
\hline
\end{tabular}


extent, migration should be more carefully discussed by the critics of her short stories and novels.

The history of South Africa may be told on the basis of the multiple spatial dislocations and displacements that eventually created the modern Republic. The already complex cultural geography engendered by the several African ethnicities that have occupied the land for millennia was further compounded by the European decision to include the Dark Continent in their imperial enterprise.

The ample bibliography on the European presence in the so-called New World has been drawing a detailed picture of the numerous social disruptions imposed by the Empire on its colonies. South Africa's situation was quite specific in that the closing days of the British administration of the country coincided with the rise to power, in 1948, of the Afrikaners, a minority white group, virulently hostile to the South African British in view of the latter's victory at the atrocious Second Boer War (1899-1902).

The new administration's ideology and action plans rested upon a project that explicitly turned racism into a state policy in order to exploit economically the black and coloured majority of the population.

From then on, the deteriorating state of social fragmentation, a major characteristic of colonial administrations, crystallised, among those who disagreed with the official policies, but could not think of a way to interfere with them, the desire to leave the country.

On top of this, the gradual increase in the level of state intolerance of criticism and of opposition movements resulted in the forced exile of a large number of South African citizens. 


\section{Nadine Gordimer's early confrontation of exile}

Within artistic and intellectual groups, since they constitute a class in which the denunciation of social injustices is normally expected, a split was slowly established between those who emigrated, whether by force or by choice, and those who opted for staying in the country hoping to find a role for their voices inside the first few manifestations of the resistance forces.

Nadine Gordimer was not exempt from the personal conflicts imposed by such a decision. While her work was not deemed particularly subversive-in the very specific meaning that this term takes on under autocratic administrations-, which, at first, spared her some typical difficulties with the state police such as pressure to leave the country, stop publishing or have her production banned, ${ }^{1}$ it was, nonetheless, driven by the need to represent the farce which the South African society was gradually turning itself into. In the process, however, the author experienced the feelings of impotence before a scenario that gained increasingly repressive and suffocating contours.

When asked about the better action to take-leave the country in search of breathable air in which to advance her career or submit to apartheid's absurdities with the intention of not losing touch with the society on which her fictional work focused-Gordimer invariably pointed to her wish to stay rather than go into self-exile. In spite of this, a considerable portion of her artistic production presents this choice in terms that reveal the high dose of internal conflict occasioned by the very need to make such a decision.

In his controversial biography of Nadine Gordimer, Ronald Suresh Roberts transcribes an excerpt from a 1958 letter addressed by the author to her friend Anthony Sampson (1926-2004), a renowned British journalist with a long writing curriculum in and about South 
Africa, in which she wonders if, after the presidential election which strengthened the power of the political parties behind apartheid, it would not be a good idea to "think again about whether we shouldn't have some provision, some plan to live elsewhere, eventually" (202).

According to Suresh Roberts, Anthony Sampson's diary contains a note, dated 11 January, 1954, which states that "Nadine Gordimer and her husband-to-be are ... going to England in April for a holiday: but I rather doubt whether they'll come back here for good-though she's very loyal to S. Africa" (202).

Despite the legal battle between the biographer and the biographee, which might render Suresh Roberts's account rather unreliable, the fragments cited by him corroborate the critical literature which asserts that Nadine Gordimer's fiction has revealed itself as an attempt to identify a function for the subject/individual who opts for staying in a repressive country and, for this reason, must cope with the dilemma of being a citizen whose background concedes him or her certain privileges under the very regime he or she is opposed to.

Gordimer's first novel, The Lying Days, was published in 1953 , that is, its writing period coincided roughly with the dates of Sampson's diary entry and Gordimer's letter to him mentioned above. In this book, normally approached by critics as a markedly autobiographical narrative, Helen Shaw, the story's narrator-cumprotagonist, describes her life since childhood through a text that, gradually, allows its reader to come into contact with the subtle forms in which racial and social prejudices were naturalised by white South African families.

The only daughter of a middle-class couple who belong to the administrative cadres of the South African powerful mining industry, Helen grows into a teenage rebel prone to defying her mother's values. 
Later on, this domestic non-conformity will be directed against the segregationist social mores that she identifies, albeit tentatively, underneath the surface of protocols which had characterised the employer-employee relationship she had witnessed from childhood.

Towards the end of the novel, a grown-up Helen is to spend the night in the port city of Durban as she prepares to leave, the following day, on a sea voyage heading for Europe. In Durban, she goes out to visit Joel, a Jewish friend from her teenage years, who happened to be likewise expecting to board a ship, only, in his case, the destination was Israel.

As they recollect a night, not too far back in their past, when she and Joel had driven to a blacks-only Johannesburg township in search of a common friend only to witness first-hand the level of police brutality inflicted on that population, Helen describes her hindsight views of those events and concludes that, as a mere spectator of state repression, from which she was shielded by her skin colour, she was no longer capable of withstanding such duplicity she seemed irrevocably condemned to by her condition. Unable to intervene in the grave political situation of her country, feeling that it was a place where things occurred "around [her], not to [her]" (Gordimer, 359), Helen chooses to live at a distance from the space where her contradiction was situated.

After leaving Joel's lodgings, Helen walks back to the hotel where she was to spend the night before her act of self-exile. In the hotel room, a dilemma settles in which will permeate most of Nadine Gordimer's later writings.

Awake in the middle of the night, Helen comes to the window and holds out her hand to catch the rain that was falling then. She gradually becomes aware of other approaching sounds. She does not comprehend immediately what they were, and the narrative effect of 
this moment bears a remarkable resemblance to the epiphanies that distinguish the European literary modernism.

But it came nearer, clearer, and it was the drowned jingle of a tambourine against small sad voices. I saw in the street below the huddled figures of some little native minstrels, singing as they padded along in the rain. The song was a popular dance tune of a few years before, "Paper Doll", but they made it infinitely mournful, infinitely longing. I stood there quite still, for a minute or more. I shall never forget how I felt. A feeling of extraordinary calm possessed me; I felt I could stand there in full possession of this great calmness forever. It did not seem to me that it would ever go. (Gordimer, 376)

One must refer back to the beginning of the novel, when the narrative portrays the social universe of Helen's childhood as a space regulated by daily duties interspersed with little festivities and pleasure moments and significantly impermeable to the privations burdened by the natives, if one is to have a better grip on how a "mournful" rendition of a ballroom song is able to convey to Helen, now an adult, the peace and quiet that she had been brought to regard as attainable through a new life in a foreign land.

The moment this sadness is revealed which underlay the purported gladness that her kind-a most gordimerian of wordsbelieved to be enjoying at the price of isolating themselves, in dances and other social gatherings, from another world, simultaneously so near, yet so distant, Helen concludes that the solution to her discomfort was not to be found in self-exile. For this reason, the protagonist draws a distinct connection between the sensation of calmness and the position of her body at that particular moment, immobile and with her feet pointing towards, albeit overhanging, the South African soil of her birth. 
It is a really felicitous move on the part of Nadine Gordimer not to steer her narrative in a melodramatic, telenovela-style direction which would have the young woman cancel her trip minutes before she was supposed to be setting out. Quite on the contrary, it is made clear that the character's departure will take place according to plan, but unburdened by the melancholy pessimism of one who seemed to be leaving in a state of existential paralysis, not knowing what she was actually in search of, leaving for.

The aftermath of Helen's epiphanic experience is described in the following terms:

My mind was working with great practicalness, and I thought to myself: Now it's all right. I'm not practicing any sort of selfdeception any longer. And I'm not running away. Whatever it was I was running away from-the risk of love? the guilt of being white? the danger of putting ideals into practice?-I'm not running away from now because I know I'm coming back here. (Gordimer, 376)

Since this decision of Helen's provides the closing touch of a typically epiphanic experience, it is not without interest that one reads that the end of The Lying Days has been described by the critic Abdul R. JanMohamed as "a deliberately anti-Joycean refusal of permanent exile and political disengagement" (96).

It is probable that the critical literature does not agree that James Joyce's self-exile, over which the author himself muses magisterially in Portrait of the Artist as a Young Man as a fundamental step for the culmination of his destiny within the universe of aesthetics, bears exclusively disengaged traits, since, to name but one example, his interrogation of the role of religion in the shaping of the Irish nation cannot be viewed as a gesture free from any political undertones. 
In any case, the exile such artistic personalities as Joyce, viewed by major experts in exile literature as a choice of circumstances capable of reducing the impact of external factors on those artists' creative task, falls under the category Nadine Gordimer is in opposition to on the closing pages of The Lying Days. Following Helen's musings, what Gordimer was in quest of was not so much an escape route as a narrative voice-probably one to sing along in the rain with the natives-that would allow her to take a public stand and, consequently, be granted artistic recognition in the land of her birth.

\section{The implications of staying}

Even if, on several occasions, Nadine Gordimer's work has been deemed inadequate for the role of social denunciation, particularly after the initial lacklustre reaction to it from the state cultural authorities, staying in South Africa was viewed by the author, and thus translated into her writing, as a fundamental step for her fiction to represent to the outside world the absurdities committed by the apartheid regime.

In JanMohamed's opinion, it was only in Burger's Daughter, Gordimer's seventh novel, published originally in 1979, that the author was able to equate the "manichean aesthetics" between leaving and staying, which had been a major source of tension in her work thus far.

Burger's Daughter is one of Nadine Gordimer's best-known novels and the only one to have been effectively censored by the apartheid cultural vigilantes. In this book, the writer fictionalises the life of Bram Fischer's (1908-1975) family. With his Afrikaner roots, Fischer gave up a promising career in the law to become one the most fiercely persecuted South African citizens, especially after his defence of Nelson Mandela during the Rivonia trials of 1963, which saw the 
great leader sentenced to life imprisonment, albeit at a significant moral cost to the official regime.

The narrative revolves around Rosa Burger, the main character, whose fictional life was inspired by the particular situation of one of the Fischers' daughters, divided by the burden of expectations created by her belonging to a family totally immersed in major political projects and personal needs that led her to question whether she was herself willing and able to make the same sacrifices imposed by the struggle on her parents.

The character's internal conflicts come to a head when, in an experience analogous to Helen Shaw's at the end of The Lying Days, Rosa gets lost in a countryside road where she witnesses the moment when a cart-driver furiously lashes his horse who, extenuated by the heavy weight he was pulling painfully, suddenly stops, unable to push on.

Rosa reacts to this disturbing scene by associating what is happening right in front of her eyes with the conventional interaction between master and slave. From then on, she draws a parallel between the cart-driver's exploitative fury and the treatment conferred on the blacks and coloureds of her country, in defence of whom her parents had been incarcerated and declared enemies of the South African nation.

As Rosa feels impotent to protect the animal from its owner, she also wakes up to her inability to contribute to the amelioration of her fellow citizens' life conditions. Consequently, she chooses to leave South Africa as a way to solve the dilemma brought about by her reluctance to take up for herself a similar destiny to that of her parents.

Rosa settles down in the south of France where she at least obtains some satisfaction for her affective needs through a life similar to the style adopted by the so-called alternative communities, which 
were very popular in the 1970s. Nevertheless, after a chance meeting with a young black South African who, in his childhood, had been brought up in her house as a sort of surrogate brother, Rosa revisits the original conflict the spell in Europe had apparently not resolved. Feeling once again interpellated, this time in a context for which she was not prepared, by the demands imposed on the South African citizens who, despite their non-exclusion by the white regime, did not align themselves to it, Rosa succumbs to the gravitational forces that will eventually bring her back to the country of her birth.

Back in South Africa, Lionel Burger's daughter decides to undertake the task she concludes is her own, both out of loyalty to her parents and from a freshly discovered affinity with the plight of the oppressed in her country. After joining agencies which worked for the benefit of the resistance movements, Rosa Burger finds herself, at the end of the novel, at the same place as she was on the first few pages of the narrative, when she was only fourteen years of age: in a jailhouse. In the opening scene, she had been brought there so she could see her mother, who had been detained by the state repressive authorities. On the second occasion, she had been herself imprisoned by the same organs responsible for persecuting her parents and their companions involved in the struggle to build a country free from racial segregation.

JanMohamed highlights the fact that, in the text, an observer states that Rosa, in the interval that existed between the two points in time, seemed to be the same young age as she was on her first visit to the prison. At this moment, the critic concludes his analysis of the conflicting dialectics identified by him in Nadine Gordimer's artistic trajectory.

Rosa's decision to choose impersonal compassion over the indulgence of personal desire is paralleled by the resolution of the dialectic of staying and leaving. (...) In Burger's Daughter 
Gordimer compresses this dialectic into a shorter but morally more significant and powerful spatial movement. The novel begins with a fourteen-year-old Rosa waiting outside the prison walls and ends with Rosa, who looks fourteen, inside the prison walls. The dialectic has been reduced to a choice between staying out of prison or being willing to risk incarceration for one's beliefs and actions. (...) The choice is now entirely a moral one; neither time, that is, the belief that somehow "time" itself will find a solution for the problems of apartheid, nor place, that is, being in South Africa or elsewhere, is a relevant criterion: either one acquiescently accepts apartheid by staying or leaving or one actively fights against it and accedes to the inevitable imprisonment. Just as Rosa willingly faces the consequences of her actions, so too Nadine Gordimer, by the very act of publishing Burger's Daughter, shows her willingness to accept, in addition to the certain banning of her novel, her own banning or house arrest or even imprisonment. (138-9)

It is my belief that Abdul JanMohamed misses the point when he reduces Nadine Gordimer's dilemma to an exclusively moral issue. The problem with his analysis lies in that the concept of the "moral" is often associated with a debate of universal ideas. In South Africa's particular political context of the late 1970's, exile functioned invariably as an option between a specific form of freedom-the one originally sought by Rosa in France-and the very real possibility of incarceration. For this reason, I agree with the critic in his assertion that Burger's Daughter revealed a radicalisation in Gordimer's trajectory vis-à-vis the authorities in her country. However, at no moment did the option for staying rather than leaving fail to make a concrete difference regarding the inevitable consequences of a declared alignment with the forces of resistance to apartheid. The strength of Nadine Gordimer's act is not only in the publication of a novel containing sharp criticism against a repressive state, but, more importantly, in her decision to stay in the country to face the 
results attendant on her choice. Her very status as a political artist -an epithet she begrudges more than rejoices in-was at stake on that occasion. This is more than moral in the ethical sense. Under a brutally autocratic regime, such a step can cost lives.

Whereas Burger's Daughter incorporates a stand taken by its author which the critical literature believes to represent her artistic coming-of-age, I prefer to question the notion that this novel also stands for a coming-to-terms with the dialectics between self-exile and staying in the country, especially in view of the fact that the book's publication paved the way for a potential forced exile.

In order to think in the terms of a resolution, one must keep in mind that, during the years in which the book was written and published, the fracture between exiles and non-exiles, or the free and the imprisoned for that matter, was beginning to settle within the national imaginary, and Nadine Gordimer by then was already perceived as an author who had chosen to stay.

For those South African citizens who, like Nadine Gordimer, had the luxury of regarding exile as an option, the time when the conflict opened up by this very possibility could finally be left behind came only through the consolidation of the negotiations that would ultimately lead to decriminalising the opposition movements. This would not be before the early 1990s.

For this reason, Nadine Gordimer's work in which she actually sought to equate the conflicts attendant on her choice to stay behind through apartheid was None to Accompany Me, her first postapartheid publication, which came out in 1994.

\section{Sell the house and come home}

The year of 1994 was undoubtedly the most festive in South Africa's recent history. The reason for such jubilation was Nelson 
Mandela's election, with both blacks and whites casting their ballots, for the post of President of the Republic of South Africa. This fact alone symbolised, even if it did not altogether implement, the end of the atrocious regime of racial segregation that had had effect since the Nationalists rose to power in 1948. The voting took place between April 27 and 29, dates described by Nadine Gordimer in the following terms:

If to be alive on this day was not Wordsworth's 'very heaven' for those who have been crushed to the level of wretchedness by the decades of apartheid and the other structures of racism that preceded it, standing in line to be living at this hour has been extraordinary. The day has been captured for me by the men and women who couldn't read or write, but underwrote it, at last, with their kind of signature. May it also be the seal on the end of illiteracy, of the pain of imposed ignorance. (157)

The recourse to the religious language, through the citation of the "heaven" of romantic poets and the revolutionary utopias, ${ }^{2}$ which is strengthened by the metaphors of the "signature" and the "seal", all this creates a picture that points to the arrival of a new moment in time for the South African nation.

It is equally interesting to note the presence of the French Revolution in its quality of leitmotiv employed whenever one wishes to invoke the idea of parting with a previous order based on injustices and privileges.

Nelson Mandela himself made use of similar language in his inaugural speech, delivered to the nation-and watched by the whole world-on May 10, 1994. On the occasion, his words ran as follows:

Today, all of us do, by our presence here, and by our celebrations in other parts of our country and the world, confer glory and hope to newborn liberty. Out of the experience of an 
extraordinary human disaster that lasted too long, must be born a society of which all humanity will be proud. (...) Each time one of us touches the soil of this land, we feel a sense of personal renewal. The national mood changes as the seasons change. We are moved by a sense of joy and exhilaration when the grass turns green and the flowers bloom. (...) The time for the healing of the wounds has come. The time to build is upon us. (...) Let freedom reign. The sun shall never set on so glorious a human achievement. (1994, my italics)

Nelson Mandela does not hesitate to phrase his speech around a project of a refoundation of South Africa. The terms highlighted in the passage above point clearly to that. To put it briefly, his country was situated at the threshold of a dream where nothing short of a radical rupture with a past of oppression, isolation and autocracy was expected.

None to Accompany Me contains two narratives that cut across each other through most of the text, although the end of the book seems to cut them off each other. The first story is that of Vera Stark and her husband Ben Stark; the second one narrates the return home of Sibongile and Didymus Maqoma, old friends of the Starks' who had fled the country after becoming active members of a major resistance movement. My focus here falls exclusively on the fascinating figure of Vera Stark.

The novel begins with Vera's reminiscences occasioned by her coming across an old photograph sent by herself, around four decades previously, to her first husband. Vera feels puzzled by the man's failure to understand the implicit message included in the photo beyond the banalities of a simple postcard. By drawing a ring around Bennet Stark's face, Vera hoped her husband would read this as her decision to get a divorce so she could start a new life with her travel companion.

Eventually, the couple separates, Vera and Ben get married and move to the house her former husband had come into from 
his parents. Through her divorce, Vera became the new owner of the property. Ben is a sculptor who makes a living by teaching. Vera is a lawyer and her work gets her involved in the defence of people displaced by the government during the period in which the government orchestrated forced removals intended to ensure that the different South African ethnicities would take up residence in different zones.

A large portion of the narrative revolves around the return to South Africa of old militants in exile and brings to the fore the friendship between the Starks and the Maqomas, as mentioned above. In the wake of this interaction between the four-with the occasional participation of the two couple's children-the book shifts its focus to concentrate on Vera's increasingly important role in resettling those citizens who, after the end of apartheid, wished to return to their original areas of residence prior to state removals. Her remarkable performance in the political sphere of the new South Africa gains her an invitation, duly accepted, to join the Technical Committee on Constitutional Issues. Her prominence as a public figure is accompanied by, or is the cause of, an intense reconfiguration of her internal, private universe.

Towards the end of the book, Vera's marriage has become a dwindling number of telephone calls she exchanges with Ben, now based in London with the couple's firstborn who, as it turns out, is the fruit of an afternoon spent by Vera with her first husband not long after their divorce. In the meantime, Vera sells her old house-"Vera's house is empty" (Gordimer, 292), says the narrator-and moves to the outbuilding of a big property bought by a former squatter camp leader she had met and made friends with during the defence of his community against multiple attempts to have them expelled from the areas they had occupied. The man, called Zeph Rapulana, is a 
member of the new black South African elite, a group that is both chastised and extolled, for different reasons, throughout the text of None to Accompany Me.

Vera's removal (no irony intended) to Zeph Rapulana's annexe echoes brilliantly Helen Shaw's frustrated attempt to have Mary Seswayo, a black college friend of hers, move to the servant's quarters -a similar annexe-of her family. Her mother thought this could be a bad idea and Mary was left with no other option than keep making the long journey from her township to attend classes, which meant dropping out somewhere before graduation for most black or poor students. ${ }^{3}$ The significance of this tectonic shift, which spans the time elapsed between a black woman being denied occupancy of an outhouse and a white woman choosing to take up residence in one, will be discussed in the final part of my paper. ${ }^{4}$

\section{My country, my people}

For critics, one essential aspect of Vera Stark is found in the various correspondences between her fictional life and the real life of her creator. To name but the most outstanding of those, one finds that both Vera and Gordimer are in their seventies while the book is being written and the story is being narrated. Besides, both women had a very short marriage in their youth followed by a long relationship with their second husbands. They both had two children, a boy and a girl, who, in their turn, have different fathers. Nadine Gordimer dedicated the book to her American grandson, Roland Stefan Cassirer, born in 1993 to her son Hugo Cassirer. Vera, too, has a grandson, Adam (the first man to a brand new world), who, in his late teens, is sent by his London-based father to live with her. Finally, to both women, sex and sexual freedom are fundamental elements to their personality. 
The novel's two epigraphs equally draw important lines connecting the two. The first-"We must never be afraid to go too far, for truth lies beyond"-is a quote from Marcel Proust, the reading of whose works had a tremendous formative impact on Gordimer's career. As the readers of Nadine Gordimer's writings know only too well, the search for truth through fiction is one of the most cherished tenets for her as a writer. When urged to produce an autobiography, the author wrote that "nothing [she writes] in (...) factual pieces will be as true as [her] fiction" (Gordimer, 1999, 14). By now, the reader must have realised that Vera's name (vera is the feminine form of the Latin adjective for true or truthful, verus) encourages the critic to associate the character with her creator's attachment to the concept of truth, which is important to her not only intellectually, but also biographically or ontologically.

The second epigraph is a haiku by the Japanese poet Bashō (1644-1694)-"None to accompany me in this path/ Nightfall in Autumn"-which creates a series of associations between nightfall and death, autumn and the end a period, along with the reflexive solitude all this entails. Nadine Gordimer and Vera Stark are no strangers to such experiences in the stages of their lives that None to Accompany Me reveals.

In conclusion, even if it proves too hurried and superficial to state grandiloquently that Vera is Nadine, there is no denying that the text contains a number of pointers that allow the critical reader to keep both biographies in mind as he or she analyses the narrative.

Between 1994 and 1995-this cannot be simply a coincidenceNadine Gordimer was invited to deliver the annual Charles Eliot Norton Lectures, a prestigious academic event within Harvard University's arts curriculum. Her final presentation was entitled That Other World that Was the World, a slightly autobiographical piece 
in which the author reflects on the slow process through which she first had to wake up to her alienation from the multitudes who lived around her, albeit at such a distance, so she could, years later, claim those as her own people.

In the lecture mentioned above, Gordimer (117) refers to Jacques, an Algerian-born character by Albert Camus who, as a child, asked his mother where or what his patrie was and concludes, from the woman's failure to come up with an answer, that la patrie "cest la France". This reminds Gordimer of her own condition as a white child born to European parents in 1920s South Africa. If she had chosen to take the cue from her mother, England would have to be her motherland. Borrowing from Italo Calvino the beautiful phraseology contained in the title of her lecture, Nadine Gordimer ponders over the weight of that long European tradition imposed on her both as a citizen of the Empire and, later, as an artist straddling the colonial and the post-colonial.

It [that other world of Europe] called. Perhaps some day, if one were lucky, very good, worked very hard, one might get to see it; and as I grew older that world took form, Dickens's and Virginia Woolf's London, Balzac's and Proust's Paris. As for America, I passed from Huck Finn to Faulkner and Eudora Welty; but America was not on the itinerary of the retired mine captains and shift bosses and their wives, my mother's friends, who saved all their lives to afford one trip "home" to England on retirement. (117-8)

Nadine Gordimer belonged to a social world restricted to the petit-bourgeois space of her country's mining industry. Black or coloured citizens were cut off from this universe, except for the servants and odd miners who sporadically crossed her path. For this reason, her early attachment to reading and writing led her 
to identify the existence of a rift between her own territory, along with the limited experiences it allowed for, and the literary space where she spent most of her free time as a child and teenager. This mismatch was compounded by the fact the South African literature of her time, at least the works most easily publicised, was produced chiefly by writers who shared with her similar backgrounds and historical attachments. As a consequence, despite an African birth, Nadine Gordimer soon becomes aware of the impossibility of calling the Dark Continent her homeland, or the Africans her people.

Following her analogy with Camus's protagonist, Gordimer (121) concludes that she would have to "make [herself], in the metaphor of The First Man, without coherent references, up on his own two legs, no model on how to proceed" (emphasis in the original). This need mirrors her desire to connect, be it with the local traditions of the continent or with the European culture she took a merely vicarious part in by means of her reading and her parents' backgrounds (Nadine Gordimer is the second daughter of a British mother and a Latvian father). As a writer, nonetheless, she would still need to perform a number of tasks expected of those artists who wish to be legitimated by the first world of world literature. In her own view, only through writing would she be able to carve a space and a role for herself in the South African society.

In my desire to write, in the writing that I was already doing out of my pathetically limited knowledge of the people and the country where I lived, was the means to find what my truth was, what was there to bond with, how I could manage to become my own First Man, woman-man, human being. (123)

Besides her literary creations, a second factor that eventually allowed Nadine Gordimer to think of South Africa as her country 
was its politically-motivated break with the British Commonwealth in 1961. With this, the notion of a European motherland would be gradually diluted. However, the author was then many years away from the final leap that would give her the much-hoped-for sense of belonging in Africa, with the Africans. Even if her work was already widely acknowledged as part of the cultural wealth of her country, her citizenship was not recognised on a similar scale, since she was still regarded by some groups as a member of the repressive, privileged white elite.

Until every law that set me aside from black people was abolished, until we were all to be born and pursue our lives everywhere in the same right, governed by the free choice of all the people, my place would not know me. No matter how I and others like me conducted ourselves, we were held in the categories of the past. The laws that provided that more money be spent on a white child's education than on a black's, that a white worker be paid more than a black worker, that black people could be transported like livestock to exist where whites decreed-all this had to go. The exiles had to come back to their rightful home; the prisoners of conscience had to be received on the mainland from Robben Island, and to walk out of Pollsmoor prison; those who had been harried and cast out had to take up the seats of power where their persecutors had ruled so long.

It came to pass.

(...) In April 1994 all South Africans of all colours went to the polls and voted into power their own government, for the first time. (...) What this means to our millions is something beyond price or reckoning (...). We know we have to perform what Flaubert called "the most difficult and least glamorous of all tasks: transition". This is the reality of freedom. This is the great matter.

I am a small matter; but for myself there is something immediate, extraordinary, of strong personal meaning. That other world that was the world is no longer the world. My country is the world, 
whole, a synthesis. I am no longer a colonial. I may now speak of "my people". (133-4)

As I prepare to bring this paper to a close, I will read this long passage alongside the closing scene of None to Accompany Me. In it, Vera is attempting to fix a leak on a pipe outside her garden house and realises she needs some tool which she expects Zeph Rapulana to have. She uses the spare key he had given her and comes into the main building in the dark. There, she ends up bumping into a young girl who had come from the man's bedroom, probably to fetch a drink at the kitchen. Scared and embarrassed, Vera rushes out back into the freezing evening air, suddenly aware that the master bedrooms of grand houses were now being occupied for the pleasure of people whose previous access to such spaces was restricted to their work as cleaners.

Vera came out into the biting ebony-blue of winter air as if she dived into the delicious shock of it. She turned off the tap with the satisfaction of a woman performing a workman-like task. Instead of at once entering her annexe she went into the garden, the jacket zipped closed over live warmth. Cold seared her lips and eyelids; frosted the arrangement of two chairs and table; everything stripped. Not a leaf on the scoured smooth limbs of the trees, and the bushes like tangled wire; dried palm fronds stiff as her fingers. A thick trail of smashed ice crackling light, stars blinded her as she let her head dip back; under the swing of the sky she stood, feet planted, on the axis of the night world. Vera walked there, for a while. And then took up her way, breath scrolling out, a signature before her. (323-4)

In a comment on this passage, Dominic Head (53) states that it is quite possible that one may underestimate it. I believe this to be correct, since most academic analyses and newspaper or journal reviews of Gordimer's novel tended to focus on the feeling of 
melancholy contained in its concluding lines, especially because this particular book deals, on the one hand, with the major political issues that dictated South Africa's society at the time when the piece was written, and, on the other, with its protagonist's ageing process, her loss of interest in the pleasures of sexuality, as well as her option for solitude.

Such elements are undoubtedly present in the final passage of the novel, but to highlight them as the most prominent ones restricts the reading of the narrative and points to a dose of insensitivity to the contentment experienced by Vera at that moment. Whereas the description of the climate and the grounds rewrites Bashō's haiku chosen by Gordimer as one of her epigraphs, Vera's body is warm, protected from the winter cold, or the internal coldness that signals the lurking presence of death. Vera's loneliness-her alonenessrepresents her liberation and serves as an analogue to her country's emancipation and the unburdening of the colonial past enacted by the sale of the old house and the removal to a corner of the former masters. By herself, her musings reformulate her previous conclusion that "everyone ends up moving alone towards the self" (306).

In my search for what can be called an autoideographical, rather than autobiographical, reading of Vera Stark vis-à-vis her creator, I would like to bring together the closing paragraphs of The Lying Days, None to Accompany Me, and the lecture That Other World That Was The World.

I have already pointed to a small detail in the last scene of Gordimer's first novel, when Helen Shaw stops by a hotel window and, as she listens to a group of natives singing a well-known song quite particularly, she declares that her trip to Europe would be temporary. The moment she realised this need to return to her country of birth, Helen was in a standing position, her feet planted 
on the floor albeit off the ground, free of contact with the soil of her country. Minutes before, the young woman had visited a friend with whom she bemoaned the condition which prevented her from belonging to anything deeper than the "crust" of the nation.

Precisely forty years later, we find Vera Stark, whose name represents the antithesis of Gordimer's first book and points to the crudeness of reality in a country where politics was grounded on ideological fallacies which the author attempted to keep as a gaping wound within the pages of her books, standing at the garden of her new home, only this time her feet are in direct contact with the soil of her new country and do not avoid this proximity. In fact, it is Vera who now belongs to the crust, if we resignify Helen's use of the term and bring to it a sense of homeliness, the white citizen's self-identification as a member of both a new country and a new people. Helen's journey comes full circle the moment Vera simultaneously takes possession of her most personal self and her public persona and bring them to terms, which is both more and less than having them coalesce. The dilution of merely personalistic references-husband and children, sex, the inherited house-makes room for the encounter with this self, this "I", unburdened of the past and involved in actions that may eventually show the way to a future dreamed of by the fathers and the mothers inside the resistance against apartheid. In collective terms, Vera encapsulates the South African intellectuals' hopes for their country in the wake of the euphoria that followed the dismantling of the atrocious regime that shamed the country for too long.

Finally, it is extremely tempting to speculate that, by choosing to compare Vera's breathing, rendered visible by the cold air in the guise of an emanation-a common gordimerian trope for the creative process-with a signature, ${ }^{5}$ Gordimer insinuates that Helen's journey, which comes to and end through Vera's internal homecoming, is 
analogous to and concomitant with her own process of arrival at a point where she could regard South Africa as her country and all South Africans as her people.

Like Sibongile and Didymus Maqoma, Vera also lived a life in exile, despite her different reasons. Vera's exile does not differ from the alienation Nadine Gordimer was subjected to during the apartheid years. With the return of the Maqomas-as well as that of the Mbekis, the Slovos, the Breytenbachs-the Starks-like the Gordimers, the Coetzees, the Brinks-were able to assume roles rendered virtually impossible by the absurd exile imposed on those who refused to leave.

\section{Notes}

1. My reference here is the beginning of Nadine Gordimer's writing career. As the government radicalised their segregation and exploitation policies, the author became eligible for the "bet-ter criteria" of the South African censors, which eventually resulted in the banning of her 1979 novel Burger's Daughter.

2. The reference for this citation is to be found in the first lines of Wordsworth's poem "French Revolution", which read as follows: "Oh! pleasant exercise of hope and joy./ For mighty were the auxiliars which then stood/ Upon our side, we who were strong in love!/ Bliss was it in that dawn to be alive,/ But to be young was very heaven!-Oh, times!/ In which the meager, stale, forbidding ways/ Of custom, law, and statute, took at once/ The at-traction of a country in romance!". See: 23 Jan. 2009. <http://www.bartleby.com/145/ww285.html>

3. Helen's mother's misgivings proved to no avail. Later on, higher education for blacks and coloureds was all but abolished in South Africa and remained so for decades.

4. I first became aware of this correlation between the two novels after reading a 1995 study of None to Accompany me written by Dominic Head. 
5. One recalls that Gordimer refers to the signature at the voting booths as a seal that trans-formed non-citizens into full-fledged South Africans on election day in 1994. Besides, the signature normally comes only when an artist believes his work has been completed.

\section{References}

Gordimer, Nadine. Burger's Daughter. New York: Penguin Books, 1980. . Living in Hope and History: Notes from our Century. New York: Farrar, Straus and Giroux, 1999. . None to Accompany Me. New York: Penguin Books, 1995. . The Lying Days. New York: Penguin Books, 1994. . Writing and Being. Cambridge, Mass.: Harvard University Press, 1996.

Head, Dominic. "Gordimer's None to Accompany Me: Revisionism and Interregnum." Research in African Literatures 26. 4 (1995): 46-57.

JanMohamed, Abdul R. Manichean Aesthetics: The Politics of Literature in Colonial Africa. Amherst: The University of Massachusetts Press, 1983.

Mandela, Nelson. "Presidential Inaugural Address". Washington State University Website. 10 Nov. 2010. <http://www.wsu.edu/ wldciv/world_civ_ reader/world_civ_reader_2/mandela.html>

Roberts, Ronald Suresh. No Cold Kitchen: A Biography of Nadine Gordimer. Johannesburg: STE Publishers, 2005.

[Received in 08/07/2011. Approved in 12/10/2011] 
